\title{
Pulmonary mechanics and surfactant measurement in canine lungs following reimplantation
}

\author{
J. C. R. LINCOLN, N. D. BARNES, T. G OULD, a nd \\ E. O.R. REY NOLDS \\ Institute of Child Health and the Department of Paediatrics, University College \\ Hospital Medical School, London W.C.1
}

\begin{abstract}
The left lung was reimplanted in 18 dogs. Failure of the venous anastomosis was the chief technical complication. Thirteen dogs survived until killed from eight days to 15 weeks after the operation. There was an immediate fall in total pulmonary compliance following the procedure, then a return to near normal within eight days. Surfactant and lung stability were normal. In each case there was a marked reduction in the gas volume of the reimplanted lung.
\end{abstract}

The chief problem that prevents the use of pulmonary transplantation as a therapeutic measure is that of graft rejection. However, problems concerning operative technique and the physiological function of the transplanted lung also remain unsolved. These may be studied by pulmonary reimplantation in animals.

Successful reimplantation of a dog's lung was first reported by Métras in 1950, and although reimplantation has been extensively studied since, an unacceptably high mortality occurs in most series (Hardy, Eraslan, and Webb, 1964 ; Guilmet, Brunet, Krakora, Leiva, and Weiss, 1965; Mouritzen, Boye, Lyager, and Ottosen, 1967). Prolonged survival of animals with a single reimplanted lung after contralateral pneumonectomy (Hill and Shaw, 1968) and with bilaterally reimplanted lungs (Faber, Pedreira, Pevsner, and Beattie, 1965) demonstrates that considerable pulmonary function may be regained. However, it is clear from these and other studies that there is impairment of function, especially in the postoperative period, after which improvement may occur. The reasons for these changes are poorly understood. This study was carried out to investigate the problems of pulmonary reimplantation with particular reference to pulmonary mechanics.

\section{METHODS}

OPERATIVE TECHNIQUE Eighteen mongrel dogs, weighing from 8.7 to $23.5 \mathrm{~kg}$., were anaesthetized with intravenous methohexitone, then maintained on nitrous oxide and oxygen via an endotracheal tube. Muscle relaxation was obtained with intravenous gallamine, and the animals were ventilated with a Manley positive pressure ventilator, $20 \mathrm{ml} . / \mathrm{kg}$. body weight per breath, at 15 breaths per minute. Compliance was then measured as described below. Using sterile techniques, thoracotomy was performed through the fifth left intercostal space. The left pulmonary artery, left main bronchus, and an intrapericardial cuff of the left atrium, together with the left pulmonary veins, were dissected free from connective tissue. The pulmonary artery was divided at the midpoint, the bronchus was transected near the take-off of the upper lobe bronchus, and a close-fitting cork was placed in the bronchus to prevent air leakage and to maintain ventilation. The cuff of left atrium with attached pulmonary veins was then excised and the lung was removed from the chest.

The pulmonary artery of the isolated lung was immediately perfused with heparinized low molecular weight dextran at $5^{\circ}$ C. $(3,000$ I.U. $/ 500 \mathrm{ml}$.) at a pressure of $40 \mathrm{~cm} . \mathrm{H}_{2} \mathrm{O}$ until the perfusate ran clear. Pressure volume studies on the isolated lung were then performed as described below. The lung was replaced in the left chest, the cuff of left atrium re-anastomosed to the cut edge of the left atrium, and the left pulmonary artery reconstructed. The vascular clamps were then synchronously removed. The bronchus was reconstituted. Continuous everting suture techniques were used on all anastomoses. The bronchial arteries, lymphatics, and nerves were not reconstructed. The lungs were inflated and the bronchial anastomosis was checked for air leaks. The average time of lung ischaemia was one hour and of no ventilation 75 minutes. The chest was then closed with underwater drains in situ. The lung was fully re-expanded and compliance was again measured. The paralysis was then reversed with neostigmine, and ventilation was continued with air until spontaneous breathing was resumed. 
Post-operatively intravascular antibiotics were given for seven days. The dogs were examined clinically and radiologically. Clinical examination of the dog's lung is difficult because of the narrow rib cage. Postero-anterior radiographs of the chest were initially taken at frequent intervals. The survivors were later re-anaesthetized, paralysed, and ventilated and compliance was measured. They were then killed; the lungs were removed immediately and perfused, and pressure volume studies were performed. Both lungs were examined histologically and, in most cases, the surface tension properties were also studied.

Surfactant Saline suspensions of parts of both lungs of nine survivors were examined for the minimum surface tension reached after two and a half hours (10 cycles) of compression and expansion of the surface in a modified Wilhelmy balance (Reynolds, Orzalesi, Motoyama, Craig, and Cook, 1965).

Total compliance Measurements were made with the dogs anaesthetized and paralysed as above and temporarily disconnected from the ventilator. The lungs were inflated from the end-expiratory position through a cuffed endotracheal tube with 100-ml. increments of air from a graduated syringe. Tracheal pressure, measured by a manometer calibrated against a water column, was recorded after each increment when the pressure had stabilized. When a pressure of $40 \mathrm{~cm}$. $\mathrm{H}_{2} \mathrm{O}$ was reached, the lungs were deflated in a similar manner. Under these conditions the error due to gaseous compression is insignificant. Compliance was estimated from the gradient of the inflation curve from 0 to $20 \mathrm{~cm}$. $\mathrm{H}_{2} \mathrm{O}$, which was linear in all cases.

Isolated lung pressure volume relationships After perfusion with heparinized dextran the isolated lung was allowed to collapse fully, a tube was secured in the bronchus, and pressure was again recorded during initial inflation to a pressure of $40 \mathrm{~cm} . \mathrm{H}_{2} \mathrm{O}$, and during deflation. With the isolated lung one minute was allowed after each increment for the pressure to stabilize fully.

The survivors were killed, and both lungs were removed, perfused, and studied separately in the same way. In some instances difficulty was experienced in removing the reimplanted lung entirely undamaged, as adhesions had formed, especially at the site of the incision. Minor leaks could be sutured, but in two cases a satisfactory preparation could not be achieved and the study was abandoned.

The lung stability index was calculated from the deflation curve by the formula of Gruenwald (1963). Lung stability was also assessed by the percentage of the maximum volume retained at $5 \mathrm{~cm}$. $\mathrm{H}_{2} \mathrm{O}$ pressure.

\section{RESULTS}

Thirteen dogs survived until killed eight days to 15 weeks after the operation. The procedure itself was well tolerated and these dogs appeared nor- mally active the following day. Apart from prophylactic antibiotics no special post-operative measures were employed. Chest radiographs showed aeration of the left lung in the immediate post-operative period, which was followed by an appearance of patchy collapse and consolidation from approximately the second to the tenth day, when these changes cleared. At necropsy the lungs looked normal, but their appearance was no guide to the patency of the vascular anastomoses. The predominant abnormality was stenosis of the upper lobe vein, which occurred in five survivors (Fig. 1), once in association with significant narrowing of the left pulmonary artery also. The

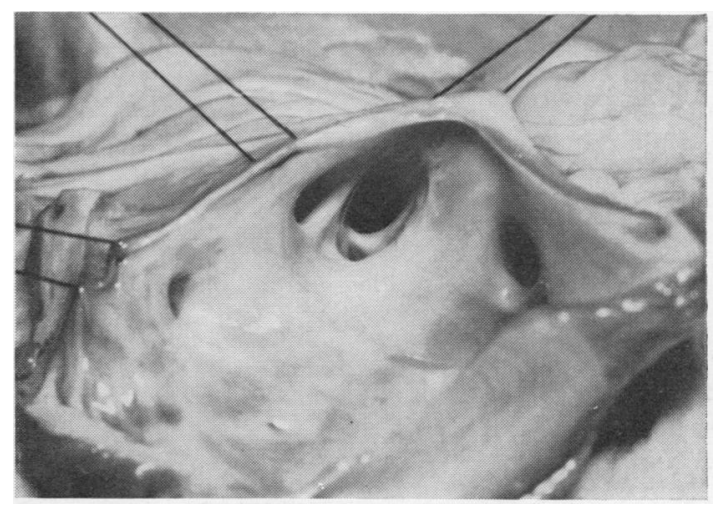

FIG. 1. Necropsy specimen showing the inside of the left atrium in a dog 12 weeks following reimplantation of the left lung. There is considerable stenosis of the left upper lobe vein at its entrance into the atrium, seen on the left side of the picture.

bronchial anastomosis was satisfactory in all cases. Eight dogs showed no macroscopic abnormality. There was no consistent pattern of histological change and, even in the presence of upper lobe vein stenosis, it was difficult to distinguish the reimplanted from the normal lung. In some cases, small areas of congestion and patchy collapse were present occasionally with organized intra-alveolar exudate. Some thickening of the pleura was usually present.

Five dogs died as a result of the procedure. The details are shown in Table I.

The results of total compliance measurements are shown in Table II. In Fig. 2 the mean compliance $/ \mathrm{kg}$. body weight \pm one standard error is shown before and after operation and for short, medium, and long-term survivors before sacrifice. It is clear that a reduction in total compliance occurred during the operation. However, by eight 
T A B L E I

THE CAUSE OF DEATH IN FIVE DOGS FOLLOWING LEFT LUNG REIMPLANTATION

\begin{tabular}{|c|c|c|}
\hline $\begin{array}{l}\text { Dog } \\
\text { No. }\end{array}$ & $\begin{array}{l}\text { No. of Days } \\
\text { Post-operative }\end{array}$ & $\begin{array}{l}\text { Necropsy } \\
\text { Findings }\end{array}$ \\
\hline 4 & 1 & $\begin{array}{l}\text { Thrombosis at the site of left atrial } \\
\text { anastomosis, lung solid with conges- } \\
\text { tion }\end{array}$ \\
\hline 6 & 2 & $\begin{array}{l}\text { Thrombosis of orifice of left pulmonary } \\
\text { veins, lung solid with congestion }\end{array}$ \\
\hline 8 & 24 & $\begin{array}{l}\text { Left pulmonary artery thrombosed, mul- } \\
\text { tiple abscesses in left lung }\end{array}$ \\
\hline 11 & 3 & $\begin{array}{l}\text { Left pulmonary artery and pulmonary } \\
\text { veins thrombosed, lung totally in- } \\
\text { farcted }\end{array}$ \\
\hline 14 & 2 & $\begin{array}{l}\text { Ball thrombus in left atrium originating } \\
\text { from atrial suture line, lung solid with } \\
\text { congestion }\end{array}$ \\
\hline
\end{tabular}

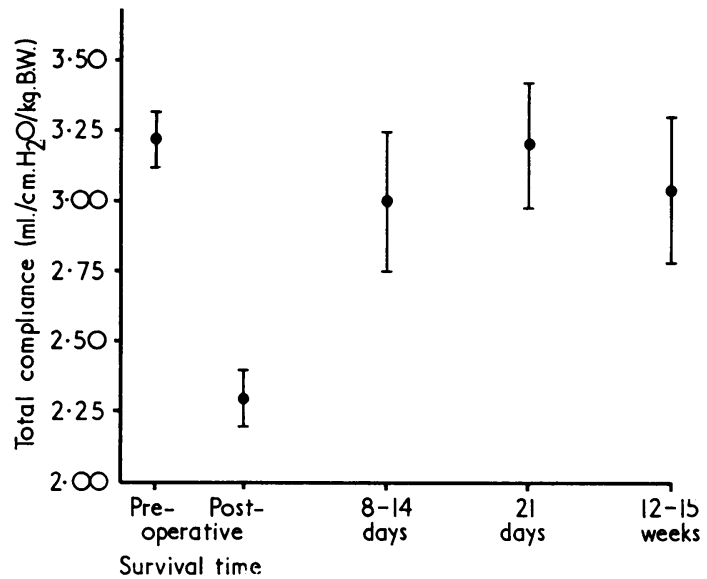

FIG. 2. Total compliance $/ \mathrm{kg}$. body weight before and after lung reimplantation and for 'short', 'medium', and 'long' survivors before sacrifice. Mean \pm 1 S.E. to 14 days the greater part of this initial loss of compliance had been regained and there was no appreciable change thereafter.

Surface tension values (Table II) were normal in all cases studied. Values of 15 dynes $/ \mathrm{cm}$. or lower are normal for this method.

Lung stability indices (normal greater than 0.9 ) and percentage air retention at $5 \mathrm{~cm} . \mathrm{H}, \mathrm{O}$ pressure (normal greater than $50 \%$ ) are shown in Table II. These were normal and showed no significant change after reimplantation. Composite pressure volume curves for all survivors are shown in Fig. 3 ; for each dog the volumes at $0,5,10,20,30$, and $40 \mathrm{~cm} . \mathrm{H}_{2} \mathrm{O}$ pressure on each inflation and deflation curve have been expressed as a percentage of the volume of the right lung at $40 \mathrm{~cm}$. $\mathrm{H}_{2} \mathrm{O}$ pressure. The composite curves were then derived from the mean values at each point, which are shown \pm one standard error. The composite curves illustrate that a gross reduction in the gas volume of the reimplanted lung occurred. At 40 $\mathrm{cm}$. $\mathrm{H}_{2} \mathrm{O}$ pressure, this reduction varied from 19 to $52 \%$ (Table II). A compensatory increase in volume of the right lung may account for the observed difference in volume between the left lung at operation and the right lung at necropsy.

\section{DISCUSSION}

Failure of the venous anastomosis was the chief complication of the operation and was the cause of death in four of the five dogs that died. However, the upper lobe vein stenosis observed in five survivors was not associated with greater changes in compliance, lung stability or volume than in

T A B L E I I

TOTAL COMPLIANCE MEASUREMENTS

\begin{tabular}{|c|c|c|c|c|c|c|c|c|c|c|c|c|c|c|}
\hline \multirow{3}{*}{ Group } & \multirow{3}{*}{ No. } & \multirow{3}{*}{$\begin{array}{c}\text { Weight } \\
\text { (kg.) }\end{array}$} & \multicolumn{3}{|c|}{$\begin{array}{c}\text { Total } \\
\text { Compliance } \\
\left(\mathrm{ml} . / \mathrm{cm} . \mathrm{H}_{2} \mathrm{O}\right)\end{array}$} & \multirow{2}{*}{\multicolumn{2}{|c|}{$\begin{array}{c}\text { Surface Tension } \\
\text { ( } \gamma \text { min., minimum } \\
\text { surface tension, } \\
\text { dynes } / \mathrm{cm} .)\end{array}$}} & \multicolumn{3}{|c|}{$\begin{array}{l}\text { Lung Stability } \\
\text { Index }\end{array}$} & \multicolumn{3}{|c|}{$\begin{array}{l}\text { Volume Retention at } \\
5 \mathrm{~cm} . \mathrm{H}_{2} \mathrm{O} \text { Pressure }\end{array}$} & \multirow{3}{*}{$\begin{array}{l}\text { Volume } \\
\text { Reduction } \\
\text { of Left } \\
\text { Lung } \\
\text { at } \\
\text { Necropsy } \\
(\%)\end{array}$} \\
\hline & & & & Poct & Before & & & \multirow{2}{*}{$\begin{array}{l}\text { Right } \\
\text { at } \\
\text { Nec- } \\
\text { ropsy }\end{array}$} & \multirow{2}{*}{$\begin{array}{c}\text { Left } \\
\text { at } \\
\text { Opera- } \\
\text { tion }\end{array}$} & \multirow{2}{*}{$\begin{array}{l}\text { Left } \\
\text { at } \\
\text { Nec- } \\
\text { ropsy }\end{array}$} & & $\mathbf{I}$ & & \\
\hline & & & $\begin{array}{l}\text { opera- } \\
\text { tive }\end{array}$ & $\begin{array}{l}\text { opera- } \\
\text { tive }\end{array}$ & $\begin{array}{c}\text { Sacri- } \\
\text { fice }\end{array}$ & $\begin{array}{l}\text { Right } \\
\text { Lung }\end{array}$ & $\begin{array}{c}\text { Left } \\
\text { Lung }\end{array}$ & & & & $\begin{array}{l}\text { Nec- } \\
\text { ropsy }\end{array}$ & $\begin{array}{l}\text { Opera- } \\
\text { tion }\end{array}$ & $\begin{array}{l}\text { Nec- } \\
\text { ropsy }\end{array}$ & \\
\hline $\begin{array}{l}\text { 'Short' } \\
\text { survivors } \\
\text { (8-14 } \\
\text { days) }\end{array}$ & $\begin{array}{l}13 \\
15 \\
16 \\
17 \\
18\end{array}$ & $\begin{array}{l}12.7 \\
27.4 \\
19.1 \\
15.0 \\
16.8\end{array}$ & $\begin{array}{l}45 \\
70 \\
52 \\
56 \\
48\end{array}$ & $\begin{array}{l}35 \\
40 \\
42 \\
36 \\
34\end{array}$ & $\begin{array}{l}45 \\
60 \\
48 \\
54 \\
46\end{array}$ & $\begin{array}{r}12 \\
7 \\
11\end{array}$ & $\begin{array}{r}5 \\
11 \\
12\end{array}$ & $\begin{array}{c}1.07 \\
0.96 \\
0.96 \\
0.96 \\
-\end{array}$ & $\begin{array}{l}1.02 \\
1.03 \\
0.98 \\
1.05 \\
1.02\end{array}$ & $\begin{array}{l}0.90 \\
0.94 \\
1.02 \\
0.95 \\
- \\
\end{array}$ & $\begin{array}{l}66 \\
55 \\
56 \\
57 \\
-\end{array}$ & $\begin{array}{l}62 \\
56 \\
59 \\
63 \\
61 \\
\end{array}$ & $\begin{array}{l}52 \\
55 \\
60 \\
57 \\
\end{array}$ & $\begin{array}{l}44 \\
47 \\
19 \\
40\end{array}$ \\
\hline $\begin{array}{l}\text { 'Medium' } \\
\text { survivors } \\
(20-21 \\
\text { days })\end{array}$ & $\begin{array}{r}9 \\
10 \\
12\end{array}$ & $\begin{array}{r}15.9 \\
9.5 \\
20.0\end{array}$ & $\begin{array}{l}44 \\
34 \\
66\end{array}$ & $\begin{array}{l}34 \cdot 5 \\
28 \\
40\end{array}$ & $\begin{array}{l}42 \\
34 \\
62\end{array}$ & $\begin{array}{l}4 \\
7 \\
5\end{array}$ & $\begin{array}{r}6 \\
10 \\
7\end{array}$ & $\begin{array}{l}1.04 \\
0.95 \\
1.01\end{array}$ & $\begin{array}{l}0.99 \\
1.04 \\
0.96\end{array}$ & $\begin{array}{l}0.94 \\
1.02 \\
0.92\end{array}$ & $\begin{array}{l}59 \\
61 \\
62\end{array}$ & $\begin{array}{l}59 \\
63 \\
60\end{array}$ & $\begin{array}{l}53 \\
58 \\
56\end{array}$ & $\begin{array}{l}27 \\
19 \\
21\end{array}$ \\
\hline $\begin{array}{l}\text { 'Long' } \\
\text { survivors } \\
(12-15 \\
\text { weeks) }\end{array}$ & $\begin{array}{l}1 \\
2 \\
3 \\
5 \\
7\end{array}$ & $\begin{array}{r}13.7 \\
23.5 \\
11.4 \\
8.7 \\
15.9\end{array}$ & $\begin{array}{l}44 \\
68 \\
50 \\
32 \\
40 \cdot 5\end{array}$ & $\begin{array}{l}35 \\
46 \\
30 \\
20 \\
36\end{array}$ & $\begin{array}{l}41 \\
62 \\
42 \cdot 5 \\
25 \\
40\end{array}$ & $\begin{array}{l}3 \\
3 \\
5\end{array}$ & $\begin{array}{l}3 \\
1 \\
8\end{array}$ & $\begin{array}{l}0.98 \\
1.01 \\
0.99 \\
1.03 \\
0.92\end{array}$ & $\begin{array}{l}0.97 \\
0.97 \\
0.96 \\
0.96 \\
0.95\end{array}$ & $\begin{array}{l}0.91 \\
0.94 \\
1.02 \\
0.91\end{array}$ & $\begin{array}{l}60 \\
61 \\
62 \\
61 \\
55\end{array}$ & $\begin{array}{l}58 \\
58 \\
58 \\
57 \\
56\end{array}$ & $\begin{array}{l}54 \\
56 \\
60 \\
52\end{array}$ & $\begin{array}{l}52 \\
19 \\
23 \\
52\end{array}$ \\
\hline
\end{tabular}




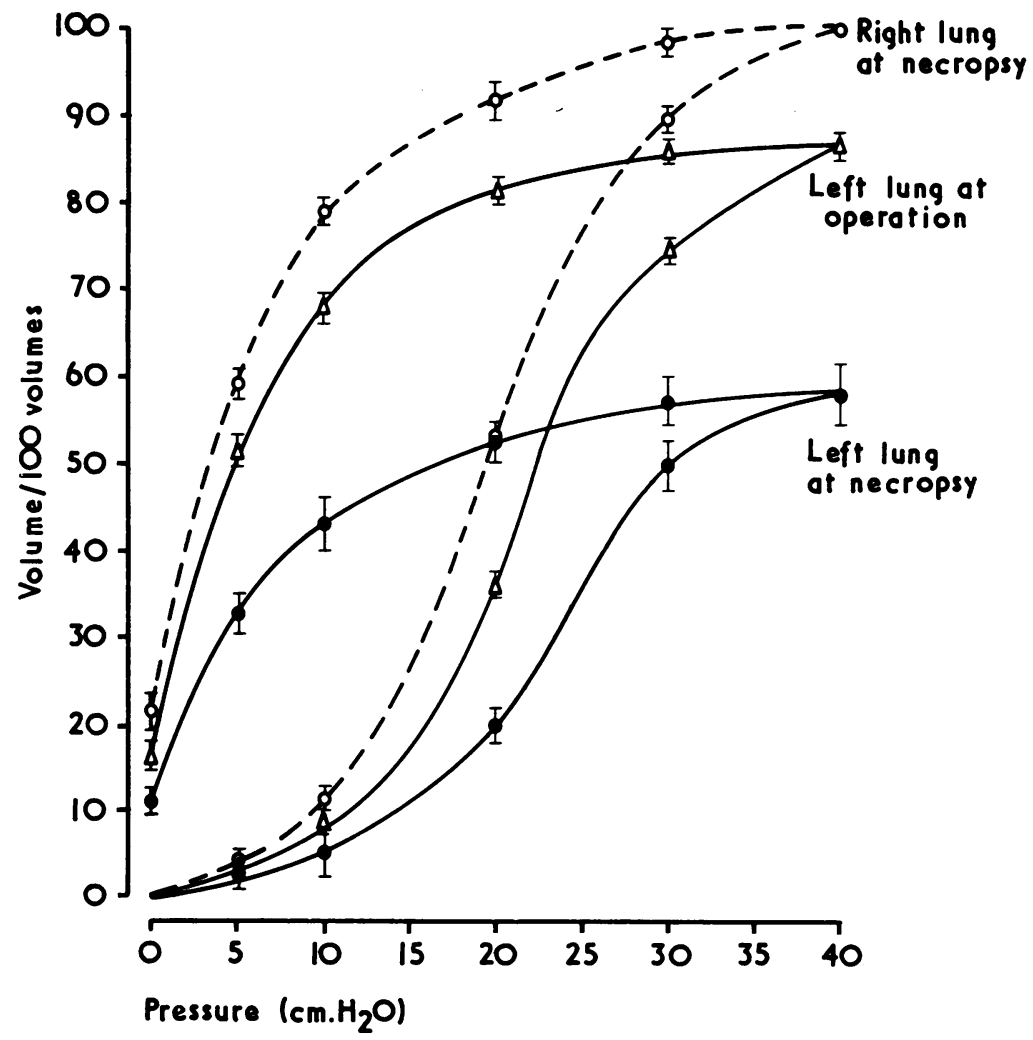

FIG. 3. Composite pressure-volume curves for the right lung at necropsy and the left lung at operation and at necropsy (after reimplantation). Mean \pm 1 S.E.

those with satisfactory anastomoses. This complication predominates in most reports of reimplantation in dogs, but it is probable that the larger size of the vessels in adult man, as in a series of baboons studied by Haglin, Telander, Muzzall, Kiser, and Strobel (1963), will make a satisfactory venous anastomosis easier to achieve.

A transplanted lung must develop adequate efficiency immediately, as most potential recipients will have severely impaired function of both lungs, and in some cases it may prove necessary to excise all or part of the contralateral lung to prevent contamination or mechanical imbalance. After lung reimplantation there is a fall in ventilation, a fall in oxygen uptake, and a moderate degree of venous-arterial shunting in the reimplanted lung, followed by gradual improvement in function (Hardy et al., 1964 ; Marshall and Gunning, 1966 ; Lyager, Mouritzen, Ottosen, and Boye, 1967 ; Birch, 1968 ; Kottmeier, Cheng, Fitzgerald, Hochman, and Emmanuel, 1969). Many factors may contribute to these changes, among which are a fall in compliance and loss of lung stability.

We have shown an immediate fall in total compliance of a degree which might cause a considerable reduction in the ventilation of the reimplanted lung. This change is not due to ventilation at fixed tidal volume during the operation, which causes a fall in compliance, because this is reversed by hyperventilation which was necessary to re-expand the reimplanted lung (Bendixen, Hedley-Whyte, and Laver, 1963). By eight to 14 days after the operation there was a return to values near those recorded preoperatively and there was no significant change thereafter. In the same period the major radiological and histological changes resolve. These changes probably represent initial clearing of diffuse atelectasis and lymphoedema, and are consistent with the findings of Eraslan, Turner, and Hardy (1964), who demonstrated lymph flow across the bronchial suture line by seven days. 
It has been postulated that lack of pulmonary surfactant may also be an important factor in the functional changes after reimplantation. Trimble, Kim, Bharadwaj, Bedard, and Wells (1966) found an immediate decrease in surfactant activity which was maximum at 48 hours, then gradually returned to normal in the following six weeks. We have demonstrated no fall in surfactant measured from eight days to 15 weeks after operation. This was confirmed by the fact that lung stability, which correlates well with direct measurements of surface tension, was also normal.

Reduction in the gas volume of the reimplanted lung has been observed in studies using xenon-133 (Strieder, Barnes, Aronow, Russell, and Kazemi, 1967) and nitrogen dilution techniques (Birch, 1968). Birch also demonstrated over-expansion of the contralateral lung. A previous study of the pressure-volume characteristics of reimplanted lungs did not reveal a fall in volume (Waldhausen, Giammona, Kilman, and Daly, 1965). However, we have demonstrated a marked fall in volume in all survivors irrespective of the state of the anastomoses or the time since operation, and without alteration in pulmonary surfactant or lung stability. If the volume of the left lung at necropsy is expressed as $100 \%$, the pressure-volume curve is almost identical to that of the right lung. This also is consistent with a primary reduction in lung volume rather than a reduction in surface active lining. Reduction in volume without alteration of surface properties must be due either to complete obstruction of airways or decreased compliance of lung tissues. Recent work (Edmunds et al., 1969) has shown that lung reimplantation may be associated with delay in mucous clearance of up to 90 days. Thus obstruction of small airways may contribute to this change and may eventually resolve. However, it is probable that, although not histologically apparent, tissue factors are also important and that these may be irreversible.
This work was supported by grants from the British Heart Foundation and the 3M Company. We wish to thank Miss M. Garrod for her full support and work in this project.

\section{REFERENCES}

Bendixen, H. H., Hedley-Whyte, J., and Laver, M. B. (1963). Impaired oxygenation in surgical patients during general anesthesia with controlled ventilation. New Engl. J. Med., 269, 991.

Birch, A. A. (1968). Pulmonary compliance and functional residual $\rightarrow$ capacity determinations in dogs with reimplanted left lungs. $J \cdot \vec{\omega}$ thorac. cardiovasc. Surg., 55, 196.

Edmunds, L. H., Jr., Stallone, R. J., Graff, P. D., Sagel, S. S., and Greenspan, R. H. (1969). Mucous transport in transplanted $\overrightarrow{\vec{x}}$ lungs of dogs. Surgery, 66, 15.

Eraslan, S., Turner, M. D., and Hardy, J. D. (1964). Lymphatic is regeneration following lung reimplantation in dogs. Surgery, 56, iv

Faber, L. P., Pedreira, A. L. S., Pevsner, P. H., and Beattie, E. J. $\vec{\infty}$ (1965). The immediate and long-term physiologic function of $\infty$ bilateral reimplanted lungs. J. thorac. cardiovasc. Surg., 50, 761.

Gruenwald, P. (1963). A numerical index of the stability of lung expansion. J. appl. Physiol., 18, 665.

Guilmet, D., Brunet, A., Krakora, P., Leiva, A., and Weiss, M. Z (1965). Contribution expérimentale á l'étude de la transplantation pulmonaire I. La réimplantation du poumon chez le chien. Technique: premiers résultats. Ann. Chir. thorac. cardiovasc., 4, 306 (Ann. Chir., 19, 558).

Haglin, J., Telander, R. L., Muzzall, R. E., Kiser, J. C., and Strobel, $\vec{\omega}$ C. J. (1963). Comparison of lung autotransplantation in the
primate and dog. Surg. Forum, 14, 196.

Hardy, J. D., Eraslan, S., and Webb, W. R. (1964). Transplantation of the lung. Ann. Surg., 160, 440.

Hill, P. McN., and Shaw, K. M. (1968). Long-term survival of dogs after experimental pulmonary reimplantation and staged contralateral pneumonectomy. Thorax, 23, 408.

Kottmeier, P. K., Cheng, C., Fitzgerald, J., Hochman, R., and صి Emmanuel, G. E. (1969). Growth and function of the replanted lung in young dogs. J. pediat. Surg., $4,66$.

Lyager, S., Mouritzen, C., Ottosen, P., and Boye, E. (1967). Lung transplantation. Pathophysiologic aspects in dogs with a re- $\bar{O}$ implanted left lung. Scand. J. thorac. cardiovasc. Surg., 1, 93.

Marshall, R., and Gunning, A. J. (1966). The long-term physiological effects of lung reimplantation in the dog. J. surg. Res., 6, 185.

Métras, H. (1950). Note préliminaire sur la grefe totale du poumon chez le chien. C.R. Acad. Sci. (Paris), 231, 1176.

Mouritzen, C., Boye, E., Lyager, S., and Ottosen, P. (1967). Lung transplantation. Experience of lung reimplantation in the dog. Scand. J. thorac. cardiovasc. Surg., 1, 87.

Reynolds, E. O. R., Orzalesi, M. M., Motoyama, E. K., Craig, J. M., and Cook, C. D. (1965). Surface properties of saline extracts from lungs of newborn infants. Acta paediat. scand., 54, 511.

Strieder, D. J., Barnes, B. A., Aronow, S., Russell, P. S., and Kazemi, H. (1967). Xenon 133 study of ventilation and perfusion in normal and transplanted dog lungs. J. appl. Physiol., 23, 359.

Trimble, A. S., Kim, J. P., Bharadwaj, B., Bedard, P., and Wells, C. (1966). Changes in alveolar surfactant after lung reimplantation. J. thorac. cardiovasc. Surg., 52, 271.

Waldhausen, J. A., Giammona, S. T., Kilman, J. W., and Daly, W. J. (1965). Effect of transplantation of canine lung on pulmonary compliance and surfactant. J. Amer. med. Ass., 191, 1002. 